\title{
ANALISIS PELAKSANAAN PERANAN PUSAT PELAYANAN TERPADU PEMBERDAYAAN PEREMPUAN DAN ANAK DALAM MENINGKATKAN PERLINDUNGAN ANAK (STUDI KASUS DI P2TP2A KABUPATEN KARAWANG)
}

\author{
Abdul Kholiq \\ Program Studi Ilmu Hukum Universitas Buana Perjuangan Karawang \\ abdulkholiq@ubpkarawang.ac.id
}

\begin{abstract}
ABSTRAK
Perlindungan anak merupakan bagian yang terpenting dalam melindungi generasi bangsa dari bahaya kejahatan yang ada di masyarakat. Anak merupakan masa yang paling mudah untuk terpengaruh oleh lingkungan sekitar. Penelitian ini bertujuan untuk mengkaji dan menelaah apa ruang lingkup tugas dan fungsi Pusat Pelayanan Terpadu Pemberdayaan Perempuan dan Anak (P2TP2A) di Kabupaten Karawang. Serta mengetahui bagaimana peran dari P2TP2A Kabupaten Karawang untuk meningkatkan perlindungan anak. Penelitian ini dilakukan di lembaga atau instansi pemerintah yakni Pusat Pelayanan Terpadu Pemberdayaan Perempuan dan Anak (P2TP2A) Kabupaten Karawang. Adapun metode yang digunakan dalam penelitian ini ialah penelitian lapangan (field research) dengan cara observasi dan wawancara langsung kepada pihak terkait. Peran dan fungsi dari Pusat Pelayanan Terpadu Pemberdayaan Perempuan dan Anak (P2TP2A) Kabupaten Karawang bertujuan untuk memberikan yang terbaik bagi anak dalam membantu menyelesaikan kasus yang dihadapi anak. Selanjutnya, upaya pendampingan dilakukan dengan beberapa tahapan perencanaan, pelaksanaan pendampingan, evaluasi dan terminasi. Kegiatan pendampingan memberika keadaan yang nyaman dan aman bagi anak yng sedang bermasalah dengan hukum. Kesimpulan dari penelitian ini memberikan pemahaman mengenai keuntungan dan manfaat dari keberadaan Pusat Pelayanan Terpadu Pemberdayaan Perempuan dan Anak di Kabupaten Karawang dalam melaksanakan kegiatan pendampingan bagi anak.
\end{abstract}

Kata Kunci: Perlindungan Anak, Pusat Pelayanan Terpadu Pemberdayaan Perempuan dan Anak (P2TP2A) 


\section{PENDAHULUAN}

Kesejahteraan sosial merupakan tujuan yang diharapkan oleh seluruh masyarakat dari pemerintah sebagai dasar untuk mewujudkan kemakmuran bagi masyarakatnya. Peningkatan kesejahteraan sosial sebagai salah satu tanda adanya keberhasilan dalam pembangunan pada suatu wilayah atau daerah artinya permasalahan-permasalahan sosial yang ada di masyarakat dapat tertangani dengan baik.

Kebijakan lain yang diambil pemerintah untuk menekankan pentingnya perlindungan hukum bagi anak korban kekerasan, maka dibentuknya lembaga khusus yaitu Pusat Pelayanan Terpadu Pemberdayaan Perempuan dan Anak (P2TP2A). Lembaga pemerintah tersebut secara khusus sebagai tempat atau wadah pendampingan terhadap anak dan perempuan yang mengalami permasalahan sosial utamanya mengenai pelanggaran hak asasi atau kekerasan seperti perdagangan manusia, kekerasan dalam rumah tangga, kekerasan seksual dan penelantaran.

Dasar hukum mengenai pembentukan Pusat Pelayanan Terpadu Pemberdayaan Perempuan dan Anak tercantum pada Peraturan Menteri Negara Pemberdayaan Perempuan dan Perlindungan Anak dengan Nomor 5 Tahun 2010 tentang Panduan Pembentukan dan Pengembangan Pusat Pelayanan Terpadu, dalam ketentuan tersebut dijelaskan bahwa pembentukan dan pengembangan pusat layanan terpadi merupakan kewajiban dan tugas masing-masing daerah termasuk di dalamnya penguatan kelembagaan dan pemenuhan sarana dan prasarana operasional dalam menunjang kegiatan lembaga pemerintah tersebut.

Kasus kekerasan terhadap perempuan dan anak yang terjadi di Kabupaten Karawang, sepanjang tahun 2016 telah mengalami peningkatan. Berdasarkan data yang dimiliki oleh Badan Pemberdayaan Perempuan dan Keluarga Berencana (BPPKB) Karawang, terdapat 45 kasus kekerasan perempuan dan anak yang dilaporkan. Jumlah tersebut mengalami kenaikan jika dibandingkan pda tahun 2015 yakni sejumah 35 kasus. Sedangkan menurut Sekretaris P2TP2A Kabupaten Karawang mengatakan bahwa mayoritas kasus yang terjadi adalah kekerasan terhadap perempuan (KDRT) ada 30 kasus, kasus perdagangan orang (trafficking) sejumlah 5 kasus diantaranya melibatkan anak di bawah umur, dan sisanya 10 kasus kekerasan yang dialami oleh anak termasuk didalamnya kekerasan seksual terhadap anak. (Media online yang diakses pada tanggal 17 Desember 2016 yakni Republika: www.republika.co.id/berita/nasional/daerah/16/12/21/oijas2359-kasus-kekerasan-terhadapanak-dan-perempuan-di-karawang-tinggi ). 
Oleh karena meningkatnya jumlah kekerasan sesksual terhadap anak di Indonesia, Pemerintah sebagai stakeholder dengan cepat mengambil kebijakan untuk menyelesaikan permasalahan sosial tersebut. Kerangka hukum terdahulu yang dibuat oleh pemerintah yakni Undang-Undang Nomor 23 Tahun 2002 Tentang Perlindungan Anak, kemudian dilakukan pembaharuan/perubahan menjadi Undang-Undang Nomor 35 Tahun 2014 sebagai langkah awal untuk menyelesaikan permasalahan kekerasan seksual anak di Indonesia. Dalam ketentuan ini mengatur bentuk permasalahan sosial anak sebagai korban kejahatan, tindakan dan tata cara pendampingan serta keterlibatan perangkat hukum dalam mewujudkan perlindungan terhadap anak.

Beranjak dari latar belakang di atas mengenai kewajiban dan tugas dari masing-masing pemerintah daerah dalam melakukan pendampingan utamanya bagi anak-anak korban kekerasan seksual, maka peneliti ingin melakukan kajian penelitian lebih lanjut mengenai bagaimana peran pemerintah daerah dalam upayanya melakukan pendampingan dan perlindungan bagi anak-anak korban kekerasan seksual sebagai permasalahan sosial. Oleh karena itu, peneliti mememilih untuk melakukan tempat penelitian di Pusat Pelayanan Terpadu Pemberdayaan Perempuan dan Anak (P2TP2A) Kabupaten Karawang.

Berdasarkan hal-hal yang telah diungkapkan dalam latar belakang, maka dibuat rumusan masalah sebagai berikut :

1. Apa ruang lingkup tugas dan fungsi dari Pusat Pelayanan Terpadu Pemberdayaan Perempuan dan Anak (P2TP2A) Kabupaten Karawang?

2. Bagaimana upaya dan langkah-langkah pendampingan oleh Pusat Pelayanan Terpadu Pemberdayaan Perempuan dan Anak (P2TP2A) dalam meningkatkan perlindungan anak di Kabupaten Karawang?

\section{METODE PENELITIAN}

Penelitian ini menggunakan metode pendekatan yuridis sosiologis yaitu untuk mengevaluasi keterkaitan aspek - aspek empiris (Burhan Ashofa, 2007:34). Metode penelitian yang dilakukan dalam program ini diawali dengan pengumpulan data awal metode deskriptif. Informasi awal yang sudah didapatkan selanjutnya akan dicari akar permasalahannya lalu dijabarkan dalam bentuk teori dengan mendapatkan dukungan bahan dari informasi kepustakaan terkait yang bersifat relevan. Program penelitian ini akan melakukan penelitian langsung terhadap lembaga atau obyek penelitiannya (penelitian lapangan). 
Sumber data merupakan asal dari mana data penelitian dapat diperoleh. Sumber data yang dipergunakan dalam penelitian ini meliputi :

a) Data Primer, merupakan data pokok yang diperlukan dalam penelitian yang berasal dari responden dan informan dan merupakan sumber data utama yang diperoleh peneliti dari :

- Responden ialah merupakan sumber data yang berupa orang dalam penelitian ini yang dijadikan responden petugas P2TP2A Kabupaten Karawang.

- Informan ialah orang yang dimanfaatkan untuk memberikan tentang situasi dan kondisi latar penelitian. Sehingga dalam penelitian ini yang menjadi informan adalah Kepala Pusat Pelayanan Terpadu Pemberdayaan Perempuan dan Anak (P2TP2A) Karawang terkait dari tugas pokok dan fungsi lembaga tersebut dalam melakukan pendampingan terhadap anak saat menghadapi permasalahan hukum.

b) Data Sekunder, merupakan data yang menunjang data primer dan merupakan pelengkap bagi data primer. Data sekunder ini merupakan data dari penelitian kepustakaan, yang terdiri dari 3 (tiga) bahan hukum yakni :

- Bahan hukum primer adalah bahan hukum yang sifatnya mengikat berupa peraturan perundang-undangan yang berlaku dan ada kaitannya dengan permasalahan yang dibahas, antara lain : Undang - Undang Nomor 35 Tahun 2014 tentang Perlindungan Anak; Undang-Undang Nomor 7 Tahun 1979 tentang Kesejahteraan Anak; dan Undang-Undang Nomor 11 Tahun 2012 Tentang Sistem Peradilan Pidana Anak.

- Bahan hukum sekunder adalah bahan hukum yang sifatnya menjelaskan bahan hukum primer, dimana bahan hukum sekunder berupa literaur, hasil karya penelitian (jurnal, karya ilmiah).

- Bahan hukum tersier adalah bahan hukum sebagai pelengkap dari kedua bahan hukum sebelumnya, yang berupa kamus hukum dan kamus bahasa Indonesia.

Teknik pengumpulan data dimaksudkan sebagai cara untuk memperoleh data dalam penelitian. Teknik pengumpulan data yang digunakan dalam penelitian ini antara lain melakukan wawancara; melakukan observasi; dan mengumpulkan dokumen-dokumen serta melakukan studi pustaka yang berkaitan dengan permasalahan yang dicari dalam penelitian ini. 
Analisis data penelitian menggunakan data kualitatif model interaktif yang berlangsung terus menerus dan berkelanjutan. Analisis model interaktif melalui berbagai alur kegiatan melalui langkah-langkah sebagai berikut :

a) Pengumpulan Data

Pengumpulan data ialah mencari dan mengumpulkan data yang diperlukan yang dilakukan terhadap berbagai jenis dan bentuk apa yang ada di lapangan kemudian data tersebut dicatat (Moleong, 2002: 106). Pengumpulan data ini dilakukan berkaitan dengan data penelitian yang ada di lapangan yaitu peneliti melakukan wawancara kepada petugas P2TP2A Karawang yang melakukan pendampingan anak dalam menghadapi permasalahan hukum yang terjadi.

b) Penyajian Data

Penyajian data ialah sekumpulan informasi tersusun yang memberi kemungkinan adanya penarikan kesimpulan dan pengambilan tindakan. Data yang diperoleh dari obyek penelitian dari data primer maupun sekunder akan disusun secara sistematis dan disajikan dalam bentuk laporan penelitian secara kualitatif yaitu berdasarkan konsep teori, peraturan perundang-undangan tentang pola pendampingan perempuan ataupun anak yang dilakukan oleh petugas P2TP2A Karawang.

c) Menarik Kesimpulan

Kesimpulan ialah suatu tinjauan ulang pada catatan lapangan atau kesimpulan dapat ditinjau sebagaimana yang muncul dari data yang harus diuji kebenarannya, kekokohan dan kecocokannya yaitu mencapai validitasnya. Pengumpulan data, reduksi data, penyajian data dan menarik simpulan sebagai suatu yang berkaitan pada saat sebelum, selama dan sesudah pengumpulan data berlangsung. Dalam hal ini peneliti mengoreksi kembali hasil penelitian dengan catatan yang terdapat di lapangan selama penelitian. Setelah data tersebut sesuai, maka dapat ditarik kesimpulan dari setiap item yang ada. tahapan analisis data kualitatif diatas melibatkan beberapa komponen data interaksi yang merupakan suatu proses siklus dalam melakukan analisis data.

\section{HASIL DAN PEMBAHASAN}

A. Ruang Lingkup Tugas Dan Fungsi Pusat Pelayanan Terpadu Pemberdayaan Perempuan Dan Anak (P2TP2A) Kabupaten Karawang 
Pembentukan Pusat Pelayanan Terpadu Pemberdayaan Perempuan dan Anak (P2TP2A) mempunyai latar belakang terkait konsep pembangunan pemberdayaan perempuan melalui Instruksi Presiden (Inpres) Nomor 9 Tahun 2000 tentang Pengarusutamaan Gender dalam Pembangunan Nasional. Konsep tersebut mempunyai tujuan yakni terselenggaranya perencanaan, penyusunan, pelaksanaan, pemantauan, dan evaluasi atas kebijakan dan program pembangunan nasional yang berperspektif gender. Sedangkan ruang dan lingkup dari konsep tersebut meliputi : perencanaan, termasuk di dalamnya perencanaan yang responsive gender/ gender budgeting; pelaksanaan; pemantauan dan evaluasi.

Pada prinsipnya setiap daerah yang akan membentuk wadah ini dapat menentukan bentuk dan nama sesuai dengan keinginan, tujuan, visi dan misi masing - masing daerah. Pembentukan Pusat Pelayanan Terpadu Pemberdayaan Perempuan dan Anak (P2TP2A) ini berbasis masyarakat, namun demikian dalam proses pembentukannya diperlukan adanya kekuatan hukum yaitu Surat Keputusan Gubernur atau Surat Keputusan Bupati setempat. Hal ini sebagai salah satu bentuk koordinasi antara pemerintah dan masyarakat. Sehingga terjadi pembagian peran antara pemerintah sebagai fasilitator dan masyarakat sebagai pelaksana di lapangan (Nining Suningsih Rochdiat, 2008:15) Dengan dikeluarkannya regulasi sebagai payung hukum di wilayah Jawa Barat yakni Peraturan Gubernur Jawa Barat Nomor 15 Tahun 2010, tepatnya pada tanggal 5 Mei 2010. Pembentukan Pusat Pelayanan Terpadu Pemberdayaan Perempuan dan Anak (P2TP2A) Kabupaten Karawang merupakan salah satu bentuk wahana pelayanan bagi perempuan dan anak dalam upaya pemenuhan informasi dan kebutuhan dibidang pendidikan, kesehatan, ekonomi, hukum, perlindungan dan penanggulangan tindak kekerasan serta perdagangan terhadap perempuan dan anak (human trafficking).

Keberadaan Pusat Pelayanan Terpadu Pemberdayaan Perempuan dan Anak (P2TP2A) Kabupaten Karawang tidak terlepas dari beberapa regulasi yang menjadi payung hukum dalam menjalankan tugas dan fungsinya. Dalam hal ini terdapat beberapa landasan hukum yang berkaitan langsung dalam menjalankan tugas dari Pusat Pelayanan Terpadu Pemberdayaan Perempuan dan Anak (P2TP2A), antara lain:

a) Batang Tubuh UUD 1945 pasal 27 ayat 2, "Tiap-tiap warga negara berhak atas pekerjaan dan penghidupan yang layak bagi kemanusiaan";

b) Batang Tubuh UUD 1945 pasal 28 A - J tentang Hak Asasi Manusia;

c) Undang-Undang Nomor 21 tahun 2007 tentang Pemberantasan Tindak Pidana Perdagangan Orang; 
d) Undang-Undang Nomor 39 tahun 1999 tentang Hak Asasi Manusia;

e) Undang-Undang Nomor 23 tahun 2004 tentang Penghapusan Kekerasan Dalam Rumah Tangga;

f) Undang-Undang Nomor 39 tahun 2004 tentang Penempatan dan Perlindungan Tenaga Kerja Indonesia di Luar Negeri;

g) Undang-Undang Nomor 13 tahun 2003 tentang Ketenagakerjaan;

h) Undang-Undang Nomor 11 tahun 2009 tentang Kesejahteraan Sosial;

i) UndangUndang Nomor 35 Tahun 2014 tentang Perubahan Atas Undang - Undang Nomor 23 Tahun 2003 tentang Perlindungan Anak;

j) Peratutan Menteri Negara Pemberdayaan Perempuan dan Perlindungan Anak Republik Indonesia Nomor 01 tahun 2010 tentang Standar Pelayanan Minimal (SPM) Bagi Perempuan dan Anak Korban Kekerasan; dan

k) Peraturan Gubernur Jawa Barat Nomor 15 tahun 2010 tentang Pusat Pelayanan Terpadu Pemberdayaan Perempuan dan Anak Provinsi Jawa Barat;

Pusat Pelayanan Terpadu Pemberdayaan Perempuan dan Anak (P2TP2A) Kabupaten Karawang mempunyai visi dan misi dalam menjelankan tugasnya. Adapun visi dan misi tersebut berkaitan erat dengan kepentingan dari semboyan pada wilayah atau daerah itu sendiri. Visi dan Misi dari Pusat Pelayanan Terpadu Pemberdayaan Perempuan dan Anak (P2TP2A) Kabupaten Karawang, yakni :

a. Visi

Optimalisasi kualitas Sumber Daya Manusia (SDM) melalui perlindungan perempuan dan anak dari tindak kekerasan sesuai dengan prinsip Hak Asasi Manusia (HAM) berlandaskan keimanan dan ketaqwaan.

b. Misi

- Menjadikan Pusat Pelayanan Terpadu Pemberdayaan Perempuan dan Anak (P2TP2A) sebagai basis pemberdayaan perempuan dan anak secara preventif kuratif dan rehabilitatif secara menyeluruh dan terpadu;

- Membangun kualitas fisik, spiritual, mental dan intelektual yang optimal untuk perempuan dan anak;

- Memberikan pelayanan yang meliputi pendampingan psikologis, advokasi serta infomrasi terhadap perempuan dan anak yangn mengalami kekerasan;

- Membangun gerakan bersama untuk mencegah dan menghapus tindakan kekerasan terhadap perempuan dan anak; 
- Membangun jejaring dan menggali potensi masyarakat dalam upaya mencegah dan menghapus kekerasan terhadap perempuan dan anak.

Pusat Pelayanan Terpadu Pemberdayaan Perempuan dan Anak (P2TP2A) Kabupaten Karawang, tentu memiliki tugas dan fungsinya sebagaimana telah dijelaskan di dalam peraturan Pemerintah Provinsi Jawa Barat.

a. Tugas

Melaksanakan sebagian tugas Pemerintah Daerah dalam menyelenggarakan pelayanan secara cepat dan terpadu dalam upaya pemberdayaan perempuan serta perlindungan anak dari tindakan kekerasan, diskriminasi dan perdagangan orang.

b. Fungsi

1) Pelaksanaan fasilitas dan penyediaan pelayanan perlindungan;

2) Penyelenggaraan koordinasi dan membangun jejaring kerja;

3) Pelaksanaan fasilitas; dan

4) Pemantauan terhadap korban penangan P2TP2A dan /atau mitra kerja.

\section{B. Upaya Dan Langkah Pendampingan Oleh Pusat Pelayanan Terpadu Pemberdayaan Perempuan Dan Anak (P2TP2A) Dalam Meningkatkan Perlindungan Anak Di Kabupaten Karawang}

Upaya Pemerintah Pusat dalam mengambil langkah kebijakan untuk menyelesaikan permasalahan sosial dan hukum terhadap anak dengan menerbitkan Undang - Undang Nomor 35 Tahun 2014 tentang Perubahan Atas Undang - Undang Nomor 23 Tahun 2002 tentang Perlindungan Anak. Adanya perubahan tersebut tidak terlepas dari meningkatnya kekerasan (seksual) yang terjadi pada anak - anak. Dalam undang - undang yang baru mengenai perlindungan anak telah mengatur tentang segala jenis permasalahan sosial dan hukum anak, tata cara pendampingan dan keterlibatan seluruh perangkat daerah dalam mensukseskan tujuan dari dilahirkannya undang - undang tersebut.

Pusat Pelayanan Terpadu Pemberdayaan Perempuan dan Anak (P2TP2A) Kabupaten Karawang terbentuk berdasarkan pada Surat Keputusan Bupati Karawang Nomor 800/Kep.671-Huk/2017. Lembaga ini merupakan bagian dari pemerintah sebagai terwakil dari Pemerintah Provinsi, Kabupaten/Kota yang akan melakukan pendampingan bagi anakanak dan perempuan yang menjadi korban kekerasan. Semenjak terbentuknya Pusat 
Pelayanan Terpadu Pemberdayaan Perempuan dan Anak (P2TP2A) Kabupaten Karawang bahwa pola kinerja pendampingan diserahkan seutuhnya kepada pihak Pusat Pelayanan Terpadu Pemberdayaan Perempuan dan Anak (P2TP2A). Permasalahan dan kasus yang telah dilaporkan atau diadukan akan ditindak lanjuti lebih awal di Pusat Pelayanan Terpadu Pemberdayaan Perempuan dan Anak (P2TP2A) agar segala sesuatu dalam menyelesaikan tugasnya menjadi tanggungjawab mengenai perlindungan, pengawasan dan pembinaan secara penuh baik disaat pendampingan di pengadilan maupun saat kasus telah selesai untuk memulihkan psikis dan keberdayaan korban. Oleh karena itu, instansi yang menjadi mitranya adalah Dinas Sosial, Dinas Pendidikan, Rumah Sakit Umum Daerah dan Kepolisian.

Proses pelaksanaan program yang terstruktur dapat mengoptimalkan proses koordinasi antara Satuan Kerja Pemerintah Daerah dan kerjasama dengan melibatkan masyarakat. Adapun program - program yang telah disiapkan oleh Pusat Pelayanan Terpadu Pemberdayaan Perempuan dan Anak (P2TP2A) diantaranya sebagai berikut :

a. Program Pencegahan (preventif)

Artinya adalah program kinerja yang sifatnya dapat mengurangi menekan atau mencegah tindakan kekerasan seksual di masyarakat bentuknya bisa berupa sosialisasi penyuluhan atau seminar.

b. Program Penindakan (kuratif dan rehabilitatif)

Artinya adalah program kinerja yang khsus diberikan kepada anakanak yang sudah menjadi korban kekerasan seksual. Pada inti dari program ini yakni melakukan pendampingan baik secara moril maupun materiil kepada anak hingga si anak tersebut mendapatkan keadilan dan kesejahteraan sehingga berdaya dikemudian hari ketika tumbuh dewasa Selain itu, pihak Pusat Pelayanan Terpadu Pemberdayaan Perempuan dan Anak (P2TP2A) juga mengembangkan kejiwaan dengan trauma healing bagi anak korban kejahatan tersebut.

Dalam pelaksanaan program kerja pendampingan diatas, diperlukan keterlibatan dari masing-masing pihak merupakan syarat mutlak dalam proses pelayanan publik. Berikut ini adalah penjelasan mengenai alur proses pelaksanaan program pencegahan (preventif) dari Pusat Pelayanan Terpadu Pemberdayaan Perempuan dan Anak (P2TP2A) Kabupaten Karawang, yakni : layanan pengaduan; klarifikasi kasus; dan kunjungan pendampingan.

Program kegiatan pendampingan oleh Pusat Pelayanan Terpadu Pemberdayaan Perempuan dan Anak (P2TP2A) Kabupaten Karawang memiliki target yang ingin dicapai dalam melaksanakan tugasnya antara lain : 
a) Pendampingan medis, yaitu merupakan pendampingan yang dilakukan oleh petugas maupun relawan dari Pusat Pelayanan Terpadu Pemberdayaan Perempuan dan Anak (P2TP2A) terhadap anak korban yang mengakibatkan luka secara fisik (badan) dan perlunya penanganan lebih lanjut dari pihak medis, misalnya anak korban kekerasan memerlukan tindakan visum;

b) Pendampingan psikologis, yaitu merupakan pendampingan dilakukan untuk anak yang mengalami trauma atau memerlukan penanganan psikologis akibat dari kekerasan yang dialaminya. Sehinggan pendampingan psikologis dilakukan oleh petugas atau relawan dari Pusat Pelayanan Terpadu Pemberdayaan Perempuan dan Anak (P2TP2A) terhadap anak korban kekerasan yang mengalami hilang rasa percaya diri, ketakutan luar biasa, cemas dan cenderung menutup diri.;

c) Pendampingan yuridis, yaitu merupakan pendampingan terhadap anak yang tersangkut permasalahan hukum. Artinya pendampingan ini khusus bagi anak yang mempunyai konflik dengan hukum serta diberikan pendampingan mencakup proses hukum yang terjadi di kepolisian, kejaksaan dan pengadilan.

Fungsi pendampingan adalah sebagai sumber penguatan bagi anak, karena anak merasa tidak sendirian dalam menghadapi permasalahan yang terjadi. Sehingga para pendamping yang senantiasa dan membantu anak menjadi semangat dan tidak putus asa dalam menghadapi permasalahan dan dapat melanjutkan masa depannya. Tindakan pendampingan ini dilakukan agar anak merasa lebih nyaman mengungkapkan semua yang dirasa dan dialami karena sudah tidak ada rasa canggung diantara anak dan pendamping tersebut. Selain itu, tujuan pendampingan bagi orang tua anak adalah bahwa orang tua merasa sangat terbantu dengan adanya pendampingan yang dilakukan khususnya mengenai penyelesaian masalah yang dihadapi anak mereka. Kemudian adanya pendampingan ini dimaksudkan agar memberikan penguatan kepada seluruh keluarga dan senantiasa membantu serta memantau perkembangan kondisi anak. Lingkungan keluarga (rumah) ikut berperan dalam memberikan penguatan baik keagamaan maupun pemulihan psikologis anak agar pendampingan berjalan secara maksimal dan kondisi anak dapat pulih kembali.

Menurut Thamrin (1996: 89) bahwa upaya dan cara untuk melakukan pendampingan salah satunya yaitu kunjungan ke lapangan, tujuan kunjungan ke lapangan ini adalah membina hubungan kedekatan dengan anak-anak korban kekerasan. Melalui kedekatan yang terjadlin maka dihasilkan akan semakin menumbuhkan kepercayaan dalam diri anak bahwa pendamping (P2TP2A) menjadi sahabat, pemerhati sekaligus orang tua bagi mereka. Alasan 
adanya kunjungan ke lapangan untuk menganai lebih dalam dalam memahami kondisi realita anak itu sendiri sebagai korban kekerasan. Dengan sikap keterbukaan dari anak, maka pendamping dapat mengidentifikasi akar permasalahan dari anak tersebut sehingga dapat menemukan solusi atau tindak lanjut terhadap permasalahan anak korban kekerasan tersebut. 


\section{Mekanisme Pelaksanaan Pendampingan Anak oleh P2TP2A Karawang}

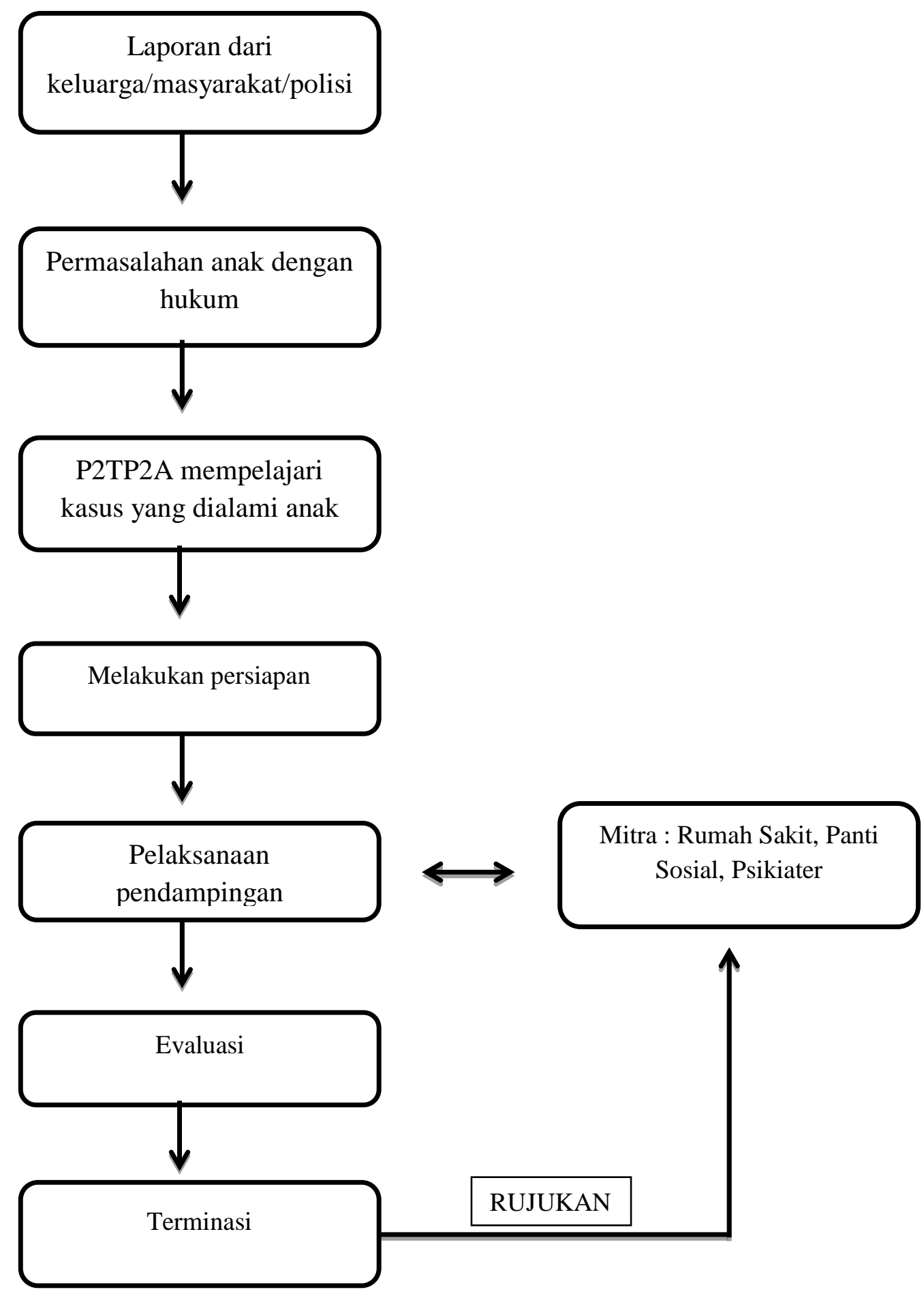


Pendampingan anak yang dilakukan oleh Pusat Pelayanan Terpadu Pemberdayaan Perempuan dan Anak (P2TP2A) merupakan cara yang digunakan dalam upaya mengembalikan anak pada kondisi keberfungsian sosial dan dapat terpenuhi semua hak -hak dari anak itu sendiri. Pendampingan yang dilakukan sudah cukup sesuai dengan tahap-tahap pelaksanaan pendampingan. Berdasarkan hasil penelitian di Pusat Pelayanan Terpadu Pemberdayaan Perempuan dan Anak (P2TP2A) Kabupaten Karawang pendampingan anak khususnya korban kekerasan yakni berupa pendampingan medis, psikologis dan yuridis. Adapun tahapan-tahapan pendampingan tersebut antara lain :

a) Persiapan

Yakni upaya untuk kegiatan pendampingan yang pertama kali dilakukan dalam mendapatkan informasi baik dari pihak kepolisian maupun masyarakat atau keluarga tentang terjadinya kekerasan yang terjadi terhadap anak. Selanjutnya akan mempelajari kasus-kasus tersebut yang mendapat mendapat prioritas atas pertimbangan urgent. Setelah melakukan perencanaan, petugas pendamping menyiapakan segala sesuatu yang dibutuhkan pada saat melaksanakan pendampingan. Persiapan mengenai materi-materi dari permasalahan yang terjadi agar berjalan dengan baik. Oleh karena itu, sebagai pendamping harus pandai dalam mempelajari permsalahan anak tersebut.

b) Pelaksanaan Pendampingan

Yakni upaya setelah melakukan perencanaan pendampingan sebelumnya, berusaha untuk menyesuaikan dengan kebutuhan anak korban kekerasan tersebut. Pendampingan ini dilakukan melalui kunjungan langsung ke lapangan (home visit). Pendekatan yang dilakukan adalah pendekatan personal (personal approach) dengan maksud untuk memahami anak secara individu. Dalam proses pendampingan, suasana dibangun sangat hangat, kekeluargaan, santai dan nonformal agar anak tersebut merasa nyaman dan leluasa untuk menyampaikan permasalahannya.

c) Evaluasi

Yakni bertujuan untuk mengetahui kelangsungan dari proses berserta faktor pendukung dan pengambatnya. Hasil serta dampak yang ditimbulkan dari pelaksanaan pendampingan sebelumnya, sehingga diperoleh dasar yang kuat untuk menetapkan langkah selanjutnya. Evaluasi dapat dilakukan antara lain dengan cara melakukan pemantauan dan pengawasan terhadap pelaksanaan kegiatan 
pendampingan, melakukan tes/meneliti kemajuan dan perubahan yang dicapai penerima manfaat maupun keluarganya. Dalam kegiatan evaluasi ini tim pendamping bekerjasama dengan keluarga klien yang ikut memantau perkembangan klien.

d) Terminasi dan rujukan

Yakni terminasi dilakukan ketika tujuan telah dicapai dan pelayanan lengkap, ketika kegiatan lebih lanjut tidak ada lagi, ketika permintaan-permintaan klien, ketika referal dibuat untuk sumber-sumber pertolongan yang lain dan pekerja sosial sudah tidak akan terlibat lama lagi.Apabila klien masih memerlukan rehabilitasi maka dari pihak Pusat Pelayanan Terpadu Pemberdayaan Perempuan dan Anak (P2TP2A) Kabupaten Karawang akan melakukan rujukan ke pantai sosial yang bersangkutan. Namun apabila sekirannya klien sudah benar-benar pulih maka akan dikembalikan ke keluarganya.

Upaya pelaksanaan pendampingan yang dilakukan oleh Pusat Pelayanan Terpadu Pemberdayaan Perempuan dan Anak (P2TP2A) Kabupaten Karawang dalam membantu menyelesaikan permasalahan anak sebagai korban, dengan tujuan yang hendak dicapai yaitu meningkatkan perlindungan hukum bagi anak tersebut sebagaimana tekah diamanatkan di dalam Undang-Undang Nomor 35 Tahun 2014 tentang Perubahan Atas Undang-Undang Nomor 23 Tahun 2002 tentang Perlindungan Anak. Segala tindakan yang berhubungan dengan anak dalam keadaan bermasalah dengan hukum maupun sosial, maka harus mengedepankan prinsip yang terbaik bagi anak (the best interest for child). Kegiatan pendampingan merupakan tindakan yang membangun sikap kekeluargaan bagi anak dengan tidak merasa terintimidasi, kurang percaya diri akibat permasalahan yang dihadapi. Oleh karena itu, dalam hal penelitian ini yang meneliti mengenai tugas dan peran dari Pusat Pelayanan Terpadu Pemberdayaan Perempuan dan Anak (P2TP2A) Kabupaten Karawang terkait manfaat serta keuntungan yang diperoleh sangat membantu bagi anak yang sedang bermasalah dengan hukum. 


\section{KESIMPULAN}

Berdasarkan hasil penelitian dan pembahasan maka dapat disimpulkan penelitian ini sebagai berikut :

1. Ruang lingkup tugas dan fungsi dari Pusat Pelayanan Terpadu Pemberdayaan Perempuan dan Anak (P2TP2A Kabupaten Karawang bagi anak-anak yang mempunyai permasalahan sosial dan hukum, bahwa tugas yang berikan harus berkaitan dengan undang-undang yang berlaku. Peran dan tugas dari P2TP2A Kabupaten Karawang dilakukan dengan mengedepankan untuk kepentingan yang terbaik bagi anak yang mampunyai permasalahan hukum.

2. Upaya pendampingan oleh Pusat Pelayanan Terpadu Pemberdayaan Perempuan dan Anak (P2TP2A) Kabupaten Karawang dalam meningkatkan perlindungan anak dilakukan dengan terencana dan terstruktur dengan baik. Pendampingan dilakukan mulai dari tahapan persiapan, pelaksanaan pendampingan, evaluasi dan terminasi (rujukan). Pelaksanaan pendampingan dilakukan melalui kunjungan langsung (home visit) kepada anak dan keluarga, selanjutnya dibangun keadaan kekeluargaan agar anak dapat merasakan nyaman ketika proses pendampingan dalam menyelesaikan permasalahan hukum yang terjadi. 


\section{DAFTAR PUSTAKA}

\section{Buku dan Karya Ilmiah}

Abdulsyani, 2007, Sosilogi Skematika, Teori, dan Terapan, Jakarta : Bumi Aksara

Ashofa, Burhan, 2007, Metode Penelitian Hukum, Jakarta : Rineka Cipta

Moleong, Lexy J. 2011. Metodologi Penelitian Kualitatif. Bandung : Rosdakarya

Mulyadi, Setyo, "Kekerasan Seksual Pada Anak", http:///www.sinarharapan.co.id

Rochdiat, Nining Suningsih, 2008, Pusat Pelayanan Terpadu Pemberdayaan Perempuan dan Anak, Newsletter Komnas Perempuan, Edisi 8 Juli 2008

Saraswati, Rika, 2009, Hukum Perlindungan Anak di Indonesia, Bandung : Citra Aditya

Sarbin T.R dan Allen V.L. "Role Theory" dalam G. Lindzey dan Aronson,eds., Handbook Of Social Psychology, 2 ${ }^{\text {nd }}$. Ed., Reading Mass: Addison Wesley Vol.1: 1968

Soekanto, Soerjono, 1989, Kegunaan Sosiologi Bagi Kalangan Hukum, Bandung : Citra bakti Aditya

Thamrin, Juni, 1996, Dehumanisasi Anak Marginal Beragai Pengalaman Pemberdayaan, Bandung: Yayasan AKATIGA

Waluyadi, 2009, Hukum Perlindungan Anak, Bandung : Mandar Maju

Wattie, Anna Marie, 2002, Kekerasan Terhadap Perempuan di Ruang Publik: Fakta, Penanganan dan Rekomendasi, Yogyakarta : PPK dan Ford Foundation

\section{Peraturan Perundang-Undangan}

Undang - Undang Nomor 23 Tahun 2002 tentang Perlindungan Anak

Undang - Undang Nomor 35 Tahun 2014 Tentang Perlindungan Anak 